\title{
The influence of microclimate and tree age on the defense capacity of European beech (Fagus sylvatica L. ) against oxidative stress
}

\author{
Gerhard Wieser $^{\mathrm{a} *}$, Karin Hecke ${ }^{\mathrm{b}}$, Michael Tausz ${ }^{\mathrm{b}}$, Karl-Heinz Häberle ${ }^{\mathrm{c}}$, Thorsten E.E. Grams ${ }^{\mathrm{c}}$ \\ and Rainer Matyssek ${ }^{\mathrm{c}}$ \\ a Bundesamt und Forschungszentrum für Wald, Abt. Forstpflanzenphysiologie, Rennweg 1, \\ 6020 Innsbruck, Austria \\ b Institute of Plant Physiology, Karl-Franzens University Graz, Schubertstraße 51, \\ 8010 Graz, Austria \\ ${ }^{c}$ Department of Ecology/Ecophysiology of Plants, Technische Universität München, Am Hochanger 13, 85354 Freising, Germany
}

(Received 1 March 2002; accepted 17 May 2002)

\begin{abstract}
Microclimate and tree age have been suggested to be factors influencing the defense capacity against oxidative stress. Therefore, 5-year-old Fagus sylvatica seedlings were grown on a scaffolding in the sun and shade crown of 55-year-old trees throughout one growing season. Independent of tree age sun leaves had a lower specific leaf area, lower pigment contents and a more capacitive antioxidative system than shade leaves. In addition, in the sun crown leaves of seedlings displayed a higher specific leaf area than leaves of adult trees. Age dependent changes in leaf morphology were related to changes in the defense capacity against oxidative stress, with area based concentrations of antioxidants and pigments increasing with tree age. Thus our results suggest that differences in the response to oxidative stress may be attributed to age and crown position related differences in the specific leaf area, the latter influencing the biochemical and physiological performance of Fagus sylvatica leaves.
\end{abstract}

Fagus sylvatica / tree age / exposure to light / antioxidative defense / specific leaf area

Résumé - L'influence du microclimat et de l'âge de l'arbre sur la capacité défensive du hêtre européen (Fagus sylvatica L.) contre le stress oxidatif. Le microclimat et l'âge de l'arbre sont considerés comme des facteurs qui influencent la capacité défensive contre le stress oxidatif. Par conséquent, des plants de Fagus sylvatica de cinq ans ont grandi sur un échafaudage à la couronne des arbres âgés de 55 ans, une fois au soleil, une autre fois à l'ombre pendant une période de croissance. Indépendamment de l'âge de l'arbre, le feuillage exposé au soleil avait une surface spécifique de la feuille inférieure, un contenu de pigment inférieur et un système antioxidatif plus puissant que le feuillage à l'ombre. De plus, au niveau de la couronne la plus haute, le feuillage des plants a développé une surface spécifique plus élevée que celui des arbres adultes. Des transformations de morphologie du feuillage, qui dépendent de l'âge des feuilles, ont été comparées avec des transformations de la capacité contre le stress oxidatif. À cela la teneur en substances antioxidatives relative à la surface de la feuille a augmenté avec l'âge de l'arbre. Donc nos résultats suggèrent que les différences de réaction au stress oxidatif peuvent être attribuées aux différences de la surface spécifique de la feuille - dépendant de l'âge et de la position à la couronne - ce qui influence la performance biochimique et physiologique des feuilles du Fagus sylvatica.

Fagus sylvatica / âge de l'arbre / exposition à la lumière / défense antioxidative / surface spécifique de la feuille / stress oxidatif

\section{INTRODUCTION}

European beech (Fagus sylvativa L.) is the most important broadleaf tree species in Central and Western Europe, covering about 12 million ha forest in this region. For the last two decades distinct deterioration of forest conditions have been reported for most of the European countries [18, 23] and [37] claimed that less than $38 \%$ of Fagus sylvatica trees in Western Europe are healthy today. The health and growth of forest trees however, is determined by a variety of natural and anthropogenic site factors. Several physiological and biochemical characteristics may be used as tools for detecting early injury preceding visible symptoms [34].

Protective pigments and antioxidants are important markers of stress to plants [30, 31]. Stress factors such as high irradiance, low temperatures, drought or air pollution are known to increase the production of reactive oxygen species [8] because of the overexcitation of the photosynthetic apparatus [9]. To counteract adverse effects of reactive oxygen species (ROS) plants possess photoprotective

* Correspondence and reprints

Tel.: 43512573933 5120; fax: 43512573933 5250; e-mail: Gerhard.Wieser@uibk.ac.at 
Table I. Specific leaf area (SLA), apparent net photosynthesis $(\mathrm{Pn})$, stomatal conductance to water vapour $\left(\mathrm{g}_{\mathrm{H} 2 \mathrm{O}}\right)$, and $\mathrm{CO}_{2}$ concentration in the mesophyll internal air spaces (Ci) in leaves of seedlings (located in the sun and shade crown of adult trees) and adult Fagus sylvatica trees in response to canopy location. Data are means of 5 trees \pm SD. Values with different letters indicate significant differences at $P<0.05$. Gas exchange data were measured in situ by means of a portable gas exchange system (LCA3; ADC, Hoddesdon, UK) and related to projected surface area.

\begin{tabular}{lcccc}
\hline & \multicolumn{2}{c}{ Sun crown } & \multicolumn{2}{c}{ Shade crown } \\
\hline SLA $\left[\mathrm{cm}^{2} \mathrm{~g} \mathrm{~g}^{-1}\right]$ & Adult & Seedling & Adult & $328.5 \pm 35.5 \mathrm{c}$ \\
$\mathrm{Pn}\left[\mu \mathrm{mol} \mathrm{m}^{-2} \mathrm{~s}^{-1}\right]$ & $100.0 \pm 18.9 \mathrm{a}$ & $243.6 \pm 21.0 \mathrm{~b}$ & $300.2 \pm 45.7 \mathrm{c}$ & $0.33 \pm 0.6 \mathrm{c}$ \\
$\mathrm{g}_{\mathrm{H} 2 \mathrm{O}}\left[\mathrm{mmol} \mathrm{m}^{-2} \mathrm{~s}^{-1}\right]$ & $2.63 \pm 0.9 \mathrm{a}$ & $6.32 \pm 1.4 \mathrm{~b}$ & $0.002 \pm 0.001 \mathrm{c}$ & $69.3 \pm 14.6 \mathrm{~b}$ \\
$\mathrm{Ci}\left[\mu \mathrm{mol}^{-} \mathrm{mol}^{-1}\right]$ & $115.5 \pm 36.8 \mathrm{a}$ & $123.4 \pm 22.5 \mathrm{a}$ & $36.0 \pm 8.8 \mathrm{~b}$ & $343 \pm 12 \mathrm{~b}$ \\
\hline
\end{tabular}

pigments and antioxidative defense systems. The former quenches excess light energy and avoid an overreduction of the photosystem [6], while the latter directly detoxifies ROS chemically or enzymatically [3, 9, 24, 31]. However, despite the economic importance of Fagus sylvatica only a few studies focused on seasonal and spatial changes of antioxidants and pigments [11, 12, 19, 29, 30]. Differences in the content of antioxidants and pigments of sun and shade leaves of Fagus sylvatica can be attributed to microclimatic differences within the canopy, the latter known to affect the specific leaf area [2, 12, 20, 41]. Moreover, little information on age-related differences in leaf morphology and oxidative defense is available. Age related changes in leaf morphology might also affect the interpretation of measured antioxidant contents as recently shown in Picea abies, where leaf-area based concentrations of antioxidants differed significantly from mass-based antioxidant concentrations, both in the sun $[39,46]$ and in the shade crown [47].

Therefore, it was the aim of this study to characterise morphological and biochemical parameters in sun and shade leaves of seedlings and adult Fagus sylvatica trees. For this purpose 4-year-old seedlings were grown in the upper and lower canopy of a 55-year-old forest stand [32] throughout one growing season. The contents of protective pigments and antioxidants of seedling and adult tree leaves were examined in response to crown position in order to evaluate whether possible alterations can contribute to explain differences in the response to oxidative stress.

\section{MATERIALS AND METHODS}

The study was conducted at the "free-air ozone fumigation plot" of Kranzberg Forest (485 m a.s.1., $48^{\circ} \mathrm{N} 11^{\circ}$ E) near Munich, Germany [14, 16, 42]. In 1998 four-year-old European beech (Fagus sylvatica L.) seedlings were planted into $70 \mathrm{~L}$ containers (20 seedlings per container) containing forest soil [13]. In order to ensure that the seedlings received the same microclimatic conditions as the leaves of 55-year-old canopy trees, five containers each were transferred into the upper sun (20 m height) and shade crown $(15 \mathrm{~m}$ height) in spring 1999. Throughout the growing season, the seedlings were watered regularly in order to avoid drought stress. Although the leaves studied differed significantly with respect to specific leaf area (table I), the values were within the range found in previous studies for sun and shade exposed leaves of adult canopy trees $[5,12,20]$ and seedlings $[2,26,41]$.
Accompanying measurements performed on neighbouring leaves immediately before harvest indicated that there were no significant differences in leaf water potential between seedlings and adult trees, neither in the shade, nor in the sun crown. Corresponding means were $-2.4 \pm 0.3 \mathrm{MPa}$ and $-1.3 \pm 0.2 \mathrm{MPa}$ for the sun and the shade crown respectively. Pre-dawn measurements assessed in seedling and adult trees one day after harvest (04:00 to 05:00 solar time) averaged $-0.12 \pm 0.02 \mathrm{MPa}$ in the sun crown and $-0.11 \pm 0.01 \mathrm{MPa}$ in the shade crown. Apparent gas exchange however, differed significantly within the leaf cohorts investigated (table I).

For the assessment of pigments and antioxidants, leaves were sampled under uniform light conditions at both canopy positions from five trees per age class (in the case of seedlings 1 per container) in September 1999 between 12:00 and 14:30, solar time. Corresponding Photosynthetic Photon Flux Densities in the sun and shade crown were $1500 \pm 200 \mu \mathrm{mol} \mathrm{m}^{-2} \mathrm{~s}^{-1}$ and $<50 \mu \mathrm{mol} \mathrm{m} \mathrm{m}^{-2} \mathrm{~s}^{-1}$, respectively. Leaves were removed from the twigs, immediately frozen in liquid nitrogen, and stored at $-80{ }^{\circ} \mathrm{C}$. The material was lyophilised and ground in a microdismembrator (Braun, Germany), and the powder was stored in humidity-proof plastic vials at $-80{ }^{\circ} \mathrm{C}$ until further biochemical analysis.

Acetone extracts were prepared to determine $\alpha$-tocopherol, using an isocratic HPLC method with fluorometric detection [43]. Reduced ascorbate and dehydroascorbate were quantified simultaneously in $\mathrm{m}$-phosphoric acid extracts after derivatisation with o-phenylenediamine [38]. Glutathione was determined in its reduced and oxidised form after labelling of thiol groups with monobromobimane [17]. Pigments were determined in acetone extracts of the leaves' dry powder, according to the HPLC gradient method described by [27].

Biochemical parameters were related to leaf dry weight and to projected leaf area, respectively. The latter has been chosen, because the external leaf surface represents the interface for the interactions between the leaf and the environment (e.g. radiation interception, gas exchange, pollutant uptake). Projected leaf area was estimated from adjacent leaves used for the biochemical analysis by means of an image analysing system, and the specific leaf area $\left(\mathrm{cm}^{2}\right.$ of projected leaf area per g leaf dry weight) was used to transform dry weight based data to surface area related values.

Differences in specific leaf area and biochemical parameters with respect to crown position and tree age were evaluated by analysis of variance (ANOVA) followed by post-hoc comparisons according to Duncan's LSD-test and was regarded significant at $P<0.05$.

\section{RESULTS}

In the present study we focused on the effects of crown position and tree age on antioxidants and photosynthetic 


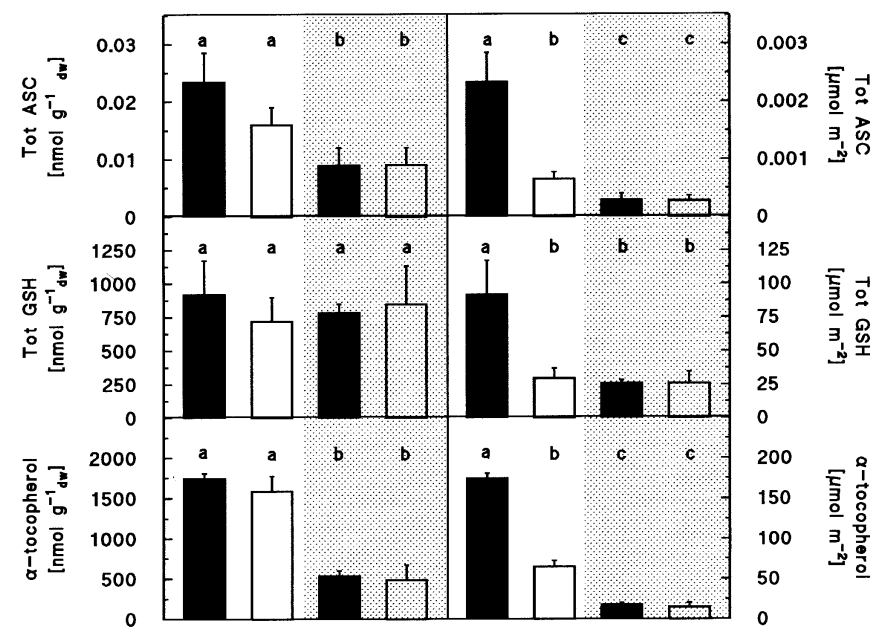

Figure 1. Total ascorbate (tot ASC), total glutathione (tot GSH) and $\alpha$-tocopherol concentrations expressed on leaf dry mass basis (left) and on leaf area basis (right) in Fagus sylvatica leaves of adult trees (closed bars) and seedling (open bars) in the sun (open area) and the shade crown (hatched area). Data are means of 5 trees \pm SD. Values with different letters indicate significant differences at $P<0.05$.

pigments in leaves of Fagus sylvatica trees. In general, most of the biochemical parameters investigated were more affected by crown position than by tree age (figures 1 and 2). On a dry mass basis sun exposed leaves of seedlings and adult canopy trees displayed significantly higher amounts of total ascorbate and $\alpha$-tocopherol (figure 1) and lower concentrations of photosynthetic pigments (figure 2) than leaves in the shade crown. Only the contents of total glutathione did not differ with respect to crown position (figure 1). Crown position also significantly affected the area based antioxidant (figure 1 ) and $\alpha$-carotene contents (figure 2). Area based contents of the other pigments by contrast, were not significantly affected by crown position (figure 2). Sun exposed leaves had a more de-epoxidised xanthophyll-cycle pool than leaves in the shade crown. Corresponding values for leaves of adult trees and seedlings were $47 \pm 7$ and $46 \pm 26 \%$ in the sun-and $7 \pm 4$ and $6 \pm 2 \%$ in the shade-crown, respectively.

When related to surface area, most biochemical parameters were also significantly affected by tree age, a fact that could not be observed, when dry weight based values were used. In the sun crown the amounts of total ascorbate, total glutathione, and $\alpha$-tocopherol (figure 1 ) as well as total chlorophyll, $\beta$-carotene, neoxanthin, lutein, and $\mathrm{V}+\mathrm{A}+\mathrm{Z}$ (figure 2) were significantly lower in seedlings than in adult trees. Similar age dependent differences were also found for lutein, and $\mathrm{V}+\mathrm{A}+\mathrm{Z}$ in the shade crown (figure 2).

The redox state of the ascorbate and glutathione pools however, were not affected neither by crown position, nor by tree age. In all the leaves investigated, $25 \pm 13 \%$ of the total needle ascorbate were found to be dehydroascorbate, and $25 \pm 6 \%$ of the total amount of glutathione was found in its oxidised state.

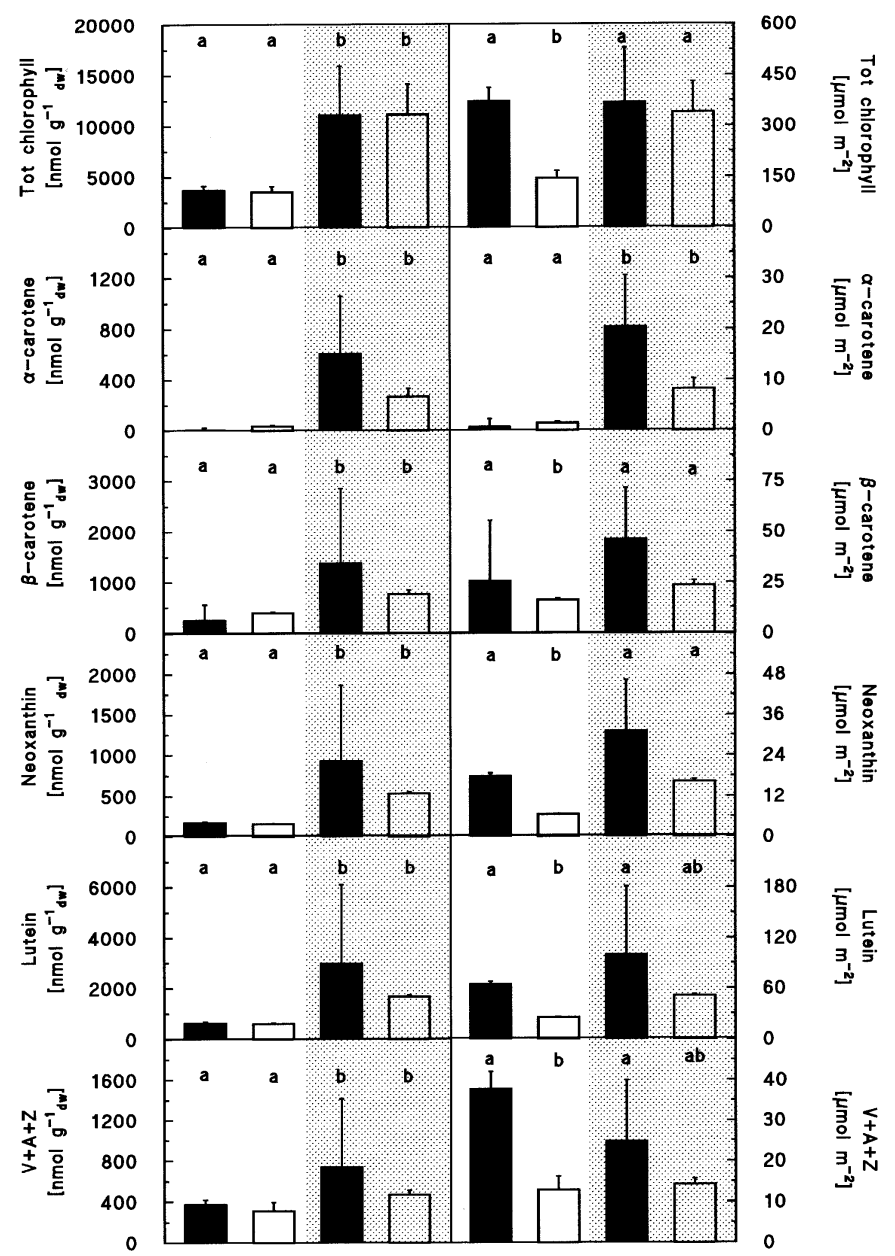

Figure 2. Photosynthetic pigments expressed on leaf dry mass basis (left) and on leaf area basis (right) in Fagus sylvatica leaves of adult trees (closed bars) and seedling (open bars) in the sun (open area) and the shade crown (hatched area). Data are means of 5 trees \pm SD. Values with different letters indicate significant differences at $P<0.05 . \mathrm{V}=$ violaxanthin, $\mathrm{A}=$ antheraxanthin, $\mathrm{Z}=$ zeaxanthin.

\section{DISCUSSION}

Dry weight based contents of antioxidants and photosynthetic pigments are widely used as markers for oxidative stress [28, 31]. In addition, leaves of beech trees with an increasing level of defoliation (or damage) showed a progressive reduction in photosynthetic pigments and antioxidants [12]. However, when focusing on environmental interactions, such as interception of radiation or uptake of air pollutants, the leaf surface is the interface between the tree and the environment. Consequently, area based values of antioxidants and photoprotective pigments are of potential importance, to relate defense capacity to environmental impacts [46], especially when tree ageing coincides with alterations in leaf morphology [39, 46, 47]. 
In coincidence with previous studies in seedling and adult Fagus sylvatica trees [12, 15, 20, 22, 26, 29, 30, 41] there were clear differences in antioxidant and pigment contents with respect to crown position. The higher dry weight and area based contents of ascorbate and $\alpha$-tocopherol in sun exposed leaves are consistent with their greater need for antioxidant protection [10]. On the other hand, dry weight based pigment contents were significantly lower in sun leaves than in shade leaves in both seedlings and adult trees. Especially the presence of $\alpha$-carotene and its much lower amounts or even loss under high light has also been described for beech $[11,12]$ and other species $[1,7,40]$. Furthermore, the smaller pool of the xanthophyll cycle pigments in sun leaves was accompanied by a higher de-epoxidation state and thus providing more photoprotection [6].

The present dry-weight related data did not show any tree age dependent differences in the composition of the biochemical parameters investigated, neither in the sun nor in the shade crown. By contrast, in the sun crown the leaf-area based concentrations of antioxidants and pigments were significantly higher in leaves of adult trees when compared to seedlings, as also obtained for Picea abies at the same study site [47]. Similar age dependent changes in antioxidant concentrations were also observed in sun-exposed needles of seedling, sapling, and adult Picea abies trees [39, 46].

Age related differences in the plant's defense capacity between area-based and dry-mass based values can be attributed to differences in leaf morphology. In the sun crown leaves of seedlings had a significantly higher specific leaf area than leaves of adult trees. Changes in specific leaf area with increasing tree age and size may indicate a change from a kind of more shade-type foliage towards a more sun type foliage, being consistent with findings from $[12,20]$ on sun and shade leaves of Fagus sylvatica. This is further corroborated by gas exchange measurements (table $I$ ) because a lower specific leaf area involves an increase in net photosynthesis when related to leaf area of Fagus sylvatica [20, 35, 36, 41] and other tree species $[4,21,25,33,44,45]$.

In conclusion, the present results indicate a higher photoprotective capacity in leaves of older Fagus sylvativa trees against leaf surface based impacts of oxidative stress such as light mediated processes or pollutant uptake. For example, differences in the $\mathrm{O}_{3}$ susceptibility of Picea abies seedlings and adult canopy trees were related to age and size dependent contrasts in the amount area based antioxidants [46]. Area-based antioxidants and pigment concentrations may help to explain differences in the response of seedling and adult trees.

Acknowledgements: This study was supported in part by the Bayrishes Staatsministerum für Landesentwicklung und Umweltfragen (Project 76a-8731.2-1997/7), the EU Project CASIROZ (EVK22002-00165), and by the Deutsche Forschungsgemeinschaft (DFG) through the Sonderforschungsbereich 607 Growth and parasite Defense - Competition for Resources in Economic Plants from Agronomy and Forestry, by Interreg II and by EU COST Action E6 Eurosilva. We also thank Mrs. Joëlle Klemmer for the translation of the French abstract.

\section{REFERENCES}

[1] Adams W.W.III., Demming-Adams B., Carotenoid composition and down regulation of photosystem II in three conifer species during the winter, Physiol. Plant. 92 (1994) 451-458.

[2] Aranda I., Bergasa L.F., Gil L., Pardos J.-A., Effects of relative irradiance on the leaf structure of Fagus sylvatica L. seedlings planted in the understory of a Pinus sylvestris L. stand after thinning, Ann. For. Sci. 58 (2001) 673-680.

[3] Asada K., The water-water cycle in chloroplasts: Scavenging of active oxygens and dissipation of excess photons, Annu. Rev. Plant. Physiol. Plant. Mol. Biol. 50 (1999) 601-639.

[4] Bauer H., Martha P., The $\mathrm{CO}_{2}$-compensation point of $\mathrm{C} 3$ plants. A re-examination. I. Interspecific variability, Z. Pflanzenphysiol. 103 (1981) 445-450.

[5] Bussotti F., Gravano E., Grossoni P., Tani C., Occurrence of tannins in leaves of beech trees (Fagus sylvativa) along an ecological gradient, detected by histochemical and ultrastructural changes, New Phytol. 138 (1998) 469-479.

[6] Demmig-Adams B., Adams W.W.III., Light stress and photoprotection related to the xanthophyll cycle, in: Foyer C.H., Mullineaux P.M. (Eds.), Causes of photooxidative stress and amelioration of defense systems in plants, CRC Press, Boca Raton, 1994, pp. 105-126.

[7] Demming-Adams B., Adams W.W.III., Chlorophyll and carotenoid composition in leaves of Euonymus kiatschovicus acclimated to different degrees of light stress in the field, Aust. J. Plant. Physiol. 23 (1996) 649-659.

[8] Elstner E.F., Osswald W., Mechanisms of oxygen activation during plant stress, Proc. Roy. Soc. Edinburgh 102B. (1994) 131-154.

[9] Foyer C., Oxygen metabolism and electron transport in photosynthesis, in: Scandalios G. (Ed.), Oxidative stress and the molecular biology of antioxidant defense, Cold Spring Harbor Laboratory Press, Cold Spring Harbor, 1997, pp. 587-621.

[10] Fryer M.J., The antioxidant effects of thylakoid vitamin E ( $\alpha$-tocopherol), Plant Cell Environm. 15 (1992) 381-392.

[11] García-Plazaola J.I., Becerril J.M., Photoprorection mechanisms in European beech (Fagus sylvatica L.) seedlings from diverse climatic origins, Trees 14 (2000) 339-343.

[12] García-Plazaola J.I., Becerril J.M., Seasonal changes in photosynthetic pigments and antioxidants in beech (Fagus sylvatica) in a Mediterranean climate: implications for tree decline diagnosis, Aust. J. Plant. Physiol. 28 (2001) 225-232.

[13] Grams T.E.E., Kozovits A.R., Reiter I.M., Winkler J.B., Sommerkorn M., Blaschke H., Häberle K.-H., Matyssek R., Quantifying competitiveness of woody plants, Plant Biology 4 (2002) 153-158.

[14] Häberle K.-H., Werner H., Fabian P., Pretzsch H., Reiter I., Matyssek R., "Free-air" ozone fumigation of mature forest trees: a concept for validating AOT40 under stand conditions, in: Fuhrer J., Achermann B. (Eds.), Critical levels for ozone - Level II, Environmental Documentation No. 115, Swiss Agency for Environment, Forest and Landscape, Bern, Switzerland, 1999, pp. 133-137.

[15] Johnson J.D., Tognetti R., Michelozzi M., Pinzauti S., Minotta G., Borghetti M., Ecophysiological responses of Fagus sylvatica L. seedlings to changing light conditions. II. The interaction of light environment and soil fertility on seedling physiology, Physiol. Plant. 101 (1999) 124-134.

[16] Karnosky D.F., Gielen B., Ceulemans R., Schlesinger W.H., Norby R.J., Oksanen E., Matyssek R., Hendrey G.R., FACE systems for studying the impacts of greenhouse gases on forest ecosystems, in: Karnosky D.F., Ceulemans R., Scarascia-Mugnozza G.E., Innes J.L. (Eds.), The impact of carbon dioxide and other greenhouse gases on forest ecosystems, CABI Publishing, Oxon, UK, 2001, pp. 297-324.

[17] Kranner I., Grill D., Content of low molecular weight thiols during the imbibition of pea seedlings, Physiol. Plant. 88 (1993) 557-562.

[18] Lorenz M., Müller-Edzards C., Becher G., Fischer R., Dibbern B., Forest condition in Europe: results of the 1998 crown condition 
survey, UN/ECE and EC Technical Report, Geneva and Brussels (1999).

[19] Luwe M., Antioxidants in the apoplast and symplast of beech (Fagus sylvatica L.) leaves: seasonal variation and responses to changing ozone concentrations in the air, Plant Cell Environ. 19 (1996) 321-328.

[20] Masarovicova E., Stefancik L., Some ecophysiological features in sun and shade leaves of tall beech trees, Biologia Plantarum 32 (1990) 374-387.

[21] McMillen G.G., McClendon J.H., Dependence of photosynthetic rates on leaf density thickness in deciduous woody plants grown in sun and shade, Plant Physiol. 72 (1983) 678-674.

[22] Minotta G., Pinzauti S., Effects of light and soil fertility on growth, leaf chlorophyll content and nutrient use efficiency of beech (Fagus sylvatica L.) seedlings, For. Ecol. Manage. 86 (1996) 61-71.

[23] Müller Edzards C., Erisman J.W., Vries W.D., Ten years of monitoring forest conditions in Europe. Studies on temporal development, spatial distribution and impacts of natural and anthropogenic stress factors, EN-UN/ECE Technical Report, Brussles and Geneva (1997).

[24] Noctor G., Foyer C.H., Ascorbate and glutathione: keeping active oxygen under control, Annu. Rev. Plant. Physiol. Plant. Mol. Biol. 49 (1998) 249-279.

[25] Oren R., Schulze E.D., Matyssek R., Zimmermann R., Estimating photosynthetic rate and annual carbon gain in conifers from specific leaf weight and leaf biomass, Oecologia 70 (1986) 187-193.

[26] Paludan-Müller G., Saxe H., Leverenz J.W., Response to ozone in 12 provenances of European beech (Fagus sylvatica): genotypic variation and chamber effects on photosynthesis and dry-matter partitioning, New Phytol. 144 (1999) 261-273.

[27] Pfeifhofer H.W., Evidence of chlorophyll b and lack of lutein in Neottia nidus-avis plastids, Biochem. Physiol. Pflanzen 184 (1989) $55-61$.

[28] Polle A., Defense against photooxidative damage in plants, in: Scandalios J.G. (Ed.), Oxidative stress and the molecular biology of antioxidant defenses, Cold Spring Harbor Laboratory Press, New York, 1997, pp. 623-666.

[29] Polle A., Morawe B., Seasonal changes in the antioxidative systems in foliar buds and leaves of field-grown beech trees (Fagus sylvatica L.) in a stressful climate, Botanica Acta 108 (1995) 314-320.

[30] Polle A., Morawe B., Rennenberg H., Seasonal variations of glutathione reductase and glutathione in leaves and leaf buds of beech trees (Fagus sylvatica L.), Phyton 32 (1992) 99-102.

[31] Polle A., Rennenberg H., Photooxidative stress in trees, In: Foyer C.H., Mullineaux P.M. (Eds.), Causes of photooxidative stress and amelioration of defense systems in plants. CRC Press, Boca Raton, 1994, pp. 199-218.

[32] Pretzsch H., Kahn M., Grote R., Die-Fichten-BuchenMischbestände des Sonderforschungsbereiches "Wachstum oder Parasitenabwehr?" im Kranzberger Forst, Forstw. Cbl. 117 (1998) 241-257.
[33] Reich P.B., Walters M.B., Ellsworth D.S., Leaf age and season influence the relation between leaf nitrogen, leaf mass per area and photosynthesis in maple and oak trees, Plant Cell Environ. 14 (1991) 251-259.

[34] Saxe H., Physiological and biochemical tools in diagnosis of forest decline and air pollution on injury to plants, in: Wiley J., Iqbal M. (Eds.), Plant response to air pollution, John Wiley and Sons, Chichester, 1996, pp. 449-489.

[35] Schulze E.-D., Der $\mathrm{CO}_{2}$-Gaswechsel der Buche (Fagus sylvatica L.) in Abhängigkeit von Klimafaktoren im Freiland, Flora 159 (1970) 177-232.

[36] Schulze E.-D., Hall A.E., Stomatal responses, water loss and $\mathrm{CO}_{2}$ assimilation rates of plants in contrasting environments, in: Lange O.L., Nobel P.S., Osmond C.B., Ziegler H. (Eds.), Encyclopedia of Plant Physiology 12B, Springer Berlin, 1982, pp. 181-230.

[37] Skärby L., Ro-Poulsen H., Wellburn F.A.M., Sheppard L.J., Impact of ozone on forest: a European perspective, New Phytol. 139 (1998) $109-122$.

[38] Tausz M., Kranner I., Grill D., Simultaneous determination of ascorbic acid and dehydroascorbic acid in plant materials by high-performance liquid chromatography, Phytochem. Analysis 7 (1996) 69-72.

[39] Tegischer K., Tausz M., Grill D., Wieser G., Tree-age and needleage dependent variations of antioxidants and photoprotective pigments in spruce needles at the alpine timberline, Tree Physiol. 22 (2002) 591-596.

[40] Thayer S.S., Björkman O., Leaf xanthophyll content and composition in sun and shade determined by HPLC, Photosynthesis Res. 23 (1990) 331-343.

[41] Tongetti R., Minotta G., Pinzauti S., Michelozzi M., Borghetti M. Acclimation to changing light conditions of long-term shade-grown beech (Fagus sylvatica L.) seedlings of different geographic origins, Trees 12 (1998) 326-333.

[42] Werner H., Fabian P., Free-air fumigation of mature trees, Environ. Sci. Pollut. Res. 9 ( 2002) 117-121.

[43] Widli B., Lütz C., Antioxidant composition of selected high alpine plant species from different altitudes, Plant Cell Environ. 19 (1996) 138-146.

[44] Wieser G., Häsler R., Götz B., Koch W., Havranek W.M., Role of climate, crown position, tree age and altitude in calculated ozone flux into needles of Picea abies and Pinus cembra: a synthesis, Environ. Pollut. 109 (2000) 415-422.

[45] Wieser G., Havranek W.M., The influence of mineral nutrition on the gas exchange of spruce, Centralblatt Ges. Forstwes. 110 (1993) $135-149$.

[46] Wieser G., Tegischer K., Tausz M., Häberle K.H., Grams T.E.E., Matyssek R., Age-effects on Norway spruce (Picea abies (L.) Karst.) susceptibility to ozone uptake. A novel approach relating stress avoidance to defense, Tree Physiol. 22 (2002a) 583-590.

[47] Wieser G., Tegischer K., Tausz M., Häberle K.H., Grams T.E.E., Matyssek R., The role of antioxidative defense in determining ozone sensitivity of Norway spruce (Picea abies (L.) Karst.) across tree age: Implications for the sun- and shade-crown, Phyton 42 (2002b) 245-253. 